\title{
Interannual variability of phytoplankton in the main rivers of the Upper Paraná River floodplain, Brazil: influence of upstream reservoirs
}

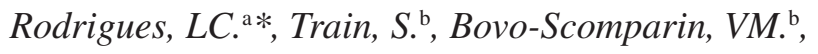 \\ Jati, S. ${ }^{\mathrm{b}}$, Borsalli, CCJ. ${ }^{\mathrm{a}}$ and Marengoni, E. ${ }^{\mathrm{a}}$ \\ aNúcleo de Pesquisas em Limnologia, Ictiologia e Aqüicultura, Universidade Estadual de Maringá - UEM, \\ Av. Colombo, 5790, Bloco H-90, Sala 23, CEP 87020-900, Maringá, PR, Brazil \\ 'Pós-Graduação em Ecologia de Ambientes Aquáticos Continentais, Departamento de Biologia, \\ Núcleo de Pesquisas em Limnologia, Ictiologia e Aqüicultura, Universidade Estadual de Maringá - UEM, \\ Av. Colombo, 5790, Bloco H-90, Sala 11, CEP 87020-900, Maringá, PR, Brazil \\ *e-mail: luziac.rodrigues@gmail.com \\ Received November 10, 2008 - Accepted March 7, 2009 - Distributed June 30, 2009
}

(With 6 figures)

\begin{abstract}
The interannual variation of phytoplankton communities in the three main rivers of the Upper Paraná River floodplain is evaluated in relation to changes in the hydrosedimentological regime. These changes are a result of climatic variability and the formation of Porto Primavera Reservoir, located at the upper Paraná River. Phytoplankton species richness and density were investigated in rivers during a prior period (1993-1994) and eight years after reservoir impoundment (2000-2007). Multiple analyses were conducted to test the differences between these time periods in order to find predictor variables for phytoplankton attributes. A total of 454 phytoplanktonic taxa were found. The regression analysis revealed significant differences between periods. In the years following construction of the Porto Primavera dam, species richness was lower in the Paraná River and density was higher in the three rivers. In general, the algal density decreased from 2005 to 2007. Diatoms and cyanobacteria contributed significantly to the total density during the period from March 1993 to February 1994. The years 2000-2007 presented the lowest diatom contribution to species richness and the highest cyanobacteria contribution. From 2000 on, cryptomonads and cyanobacteria dominated. The interannual variability of phytoplankton was probably influenced by changes in hydrosedimentological regime due to climatic variations (La Niña and El Niño - Southern Oscillation events - ENSO) and the operational procedures associated with an upstream reservoirs. Studies on climatic variability and its effects on hydrosedimentological regimes of the Paraná, Baía and Ivinhema rivers and the biota therein are necessary to obtain subsidies for management, including decisions related to the operation of dams upstream and downstream of the study area, with the purpose of minimizing risks to the Environmental Protection Area.
\end{abstract}

Keywords: potamoplankton, interannual variability, species richness and density, regulated rivers, Upper Paraná River floodplain.

\section{Variabilidade Interanual do Fitoplâncton dos principais rios da planície de inundação do Alto Rio Paraná, Brasil: influência de reservatórios a montante}

\section{Resumo}

A variação interanual da estrutura fitoplanctônica nos três principais rios da planície de inundação do Alto Rio Paraná foi avaliada em relação às modificações no regime hidrossedimentológico. Essas modificações são resultantes da variabilidade climática e da formação do reservatório de Porto Primavera, localizado no Alto Rio Paraná. Foi avaliada a riqueza de espécies e a densidade, em um período anterior à construção da UHE de Porto Primavera (1993-1994) e nos 8 anos seguintes (2000-2007) a formação do reservatório. Foram realizadas análises de regressão múltipla para testar as diferenças entre os períodos e buscar variáveis preditoras dos atributos fitoplanctônicos analisados. Foram registrados 454 táxons. A análise de regressão evidenciou variações significativas entre os períodos analisados. A riqueza de espécies foi menor no Rio Paraná e a densidade fitoplanctônica foi maior nos três rios nos anos seguintes à formação do reservatório de Porto Primavera. Registrou-se um decréscimo nos valores de densidade nos anos de 2005 a 2007. Diatomáceas e cianobactérias contribuíram significativamente para a densidade durante o período de março de 1993 a fevereiro de 1994. No período de 2000 a 2007 ocorreu menor contribuição de diatomáceas e, maior contribuição de 
cianobactérias para a riqueza de espécies. A partir de 2000, criptofíceas e cianobactérias dominaram. As alterações nos atributos analisados também estiveram associadas às flutuações no regime hidrossedimentológico dos rios estudados, provavelmente, influenciadas pelas fases La Niña e El Niño (Oscilação Sul - ENOS). Estes resultados salientam a necessidade de estudos enfocando a variabilidade climática e seus efeitos sobre o regime hidrossedimentológico do Rio Paraná e, sobre sua biota, de modo a fornecer subsídios para o manejo adequado, incluindo decisões quanto à operação das barragens situadas a montante e jusante da região de estudo, para minimizar as perdas de biodiversidade nesta Área de Preservação Ambiental.

Palavras-chave: potamoplâncton, variabilidade interanual, riqueza de espécies e densidade, rios regulados, planície de inundação do Alto Rio Paraná.

\section{Introduction}

River segment characteristics reflect interactions among multiple factors acting on different spatial and temporal scales (e.g., geomorphology, climatic and natural disturbances), which can induce changes in aquatic communities (Lair and Reys-Marchant, 1997). Changes in the hydrosedimentological regime of floodplain rivers (sensu Neiff, 1996) have significant effects on these ecosystems (Ward et al., 1999), and those promoted by operational procedures associated with upstream dams are among the principal anthropogenic alterations of floodplains systems (Agostinho et al., 2008; Souza Filho, 2009). For instance, the effects of impoundments on the upper Paraná River increased after the filling of the Porto Primavera Reservoir (Souza Filho et al., 2004), leading to a remarkable increase of water transparency, reduction of phosphorus concentrations and decrease of Paraná River discharge.

The hydrodynamic conditions of reservoirs favor the development of phytoplankton (Train et al., 2005; Borges et al., 2008a), which can be transported for some distance downstream (Lair and Reys-Marchant, 1997; Silva et al., 2001; Soares et al., 2007). The potamoplankton is characterized by a relatively high proportion of rare species and storage zones of rivers maintain innocula and promote the enhancement of downstream phytoplankton populations (Rojo et al., 1994; Reynolds, 1994; Lair and Reyes-Marchant, 1997).

In the last two decades, the influence of variation in hydrosedimentological regime on phytoplankton from the Paraná (Train and Rodrigues, 2004; Devercelli, 2006; Zalocar de Domitrovic et al., 2007), Baía and Ivinhema rivers has been analyzed. Certain relationships among climatic factors have been identified (Train and Rodrigues, 1998; Train and Rodrigues, 2004; Bovo-Scomparin and Train, 2008), such as the dominance of cyanobacteria in La Niña periods, characterized by lower precipitation and reduced Paraná River fluviometric levels, as well as the dominance of diatoms and cryptomonadas in El Niño periods, when higher values of precipitation, higher fluviometric levels and greater Paraná River discharge were observed.

Despite the great number of impoundments in the Paraná River watershed (Agostinho et al., 2008), studies assessing their impacts and the influence of climatic variability on the potamoplankton of these systems are scarce.
This study aimed to evaluate the interannual variability of phytoplankton in the Paraná, Baía and Ivinhema rivers after the formation of the Porto Primavera Reservoir. We compared these data to those of a former, pre-reservoir period that comprised a complete hydrological cycle. We also evaluated the influence of environmental variables on the phytoplankton community, hypothesizing that the lowest fluviometric and river discharge result in decreased species richness, due to a reduced connectivity between the river-floodplain system. Similarly, increased density values result from higher light availability and reduced current velocity.

\section{Material and Methods}

This study was conducted at the upper Paraná - PR $\left(22^{\circ} 43^{\prime} \mathrm{S}\right.$ and $\left.53^{\circ} 13^{\prime} \mathrm{W}\right)$, Ivinhema - MS $\left(22^{\circ} 47^{\prime} \mathrm{S}\right.$ and $\left.53^{\circ} 32^{\prime} \mathrm{W}\right)$, and Baía - MS $\left(22^{\prime} 43^{\circ} \mathrm{S}\right.$ and $\left.53^{\prime} 17^{\circ} \mathrm{W}\right)$ rivers in Brazil (Figure 1). These rivers are responsible for the hydrographic drainage of the upper Paraná watershed. The Paraná River has variable width, with islands and sandbars, and maximum depth of $4.0 \mathrm{~m}$ in the stretch studied. This river is associated with a very large floodplain. Due to its importance as a representative of a local river-floodplain system, it was transformed into an Environmental Protection Area (APA) to preserve the islands and "Várzeas" of the Paraná River. This APA comprises all portions of the upper Paraná River that have not yet been dammed; these extending from the mouth of the Paranapanema River to the beginning of the Itaipu Reservoir. The mean flow velocity of the upper Paraná River during the $1993-94$ period was $0.88 \mathrm{~m} / \mathrm{s}$; from 2000 to 2007 , this value was $0.60 \mathrm{~m} / \mathrm{s}$. The Ivinhema River, an important tributary of the right bank of the Paraná River, shows a width:depth ratio of 22:1 and high current flows (about $0.85 \mathrm{~m} / \mathrm{s}$ ).

The Baía River is a tributary of the right bank of the upper Paraná River; it shows a width: depth ratio of 18:1 and varies considerably in flow velocity during the different phases of the hydrological cycle. During flood periods, the current velocities decrease and the current may reverse and flow upstream, due to the entry of water from the Paraná River. The construction of the Porto Primavera earth dam interrupted the Baía River system 


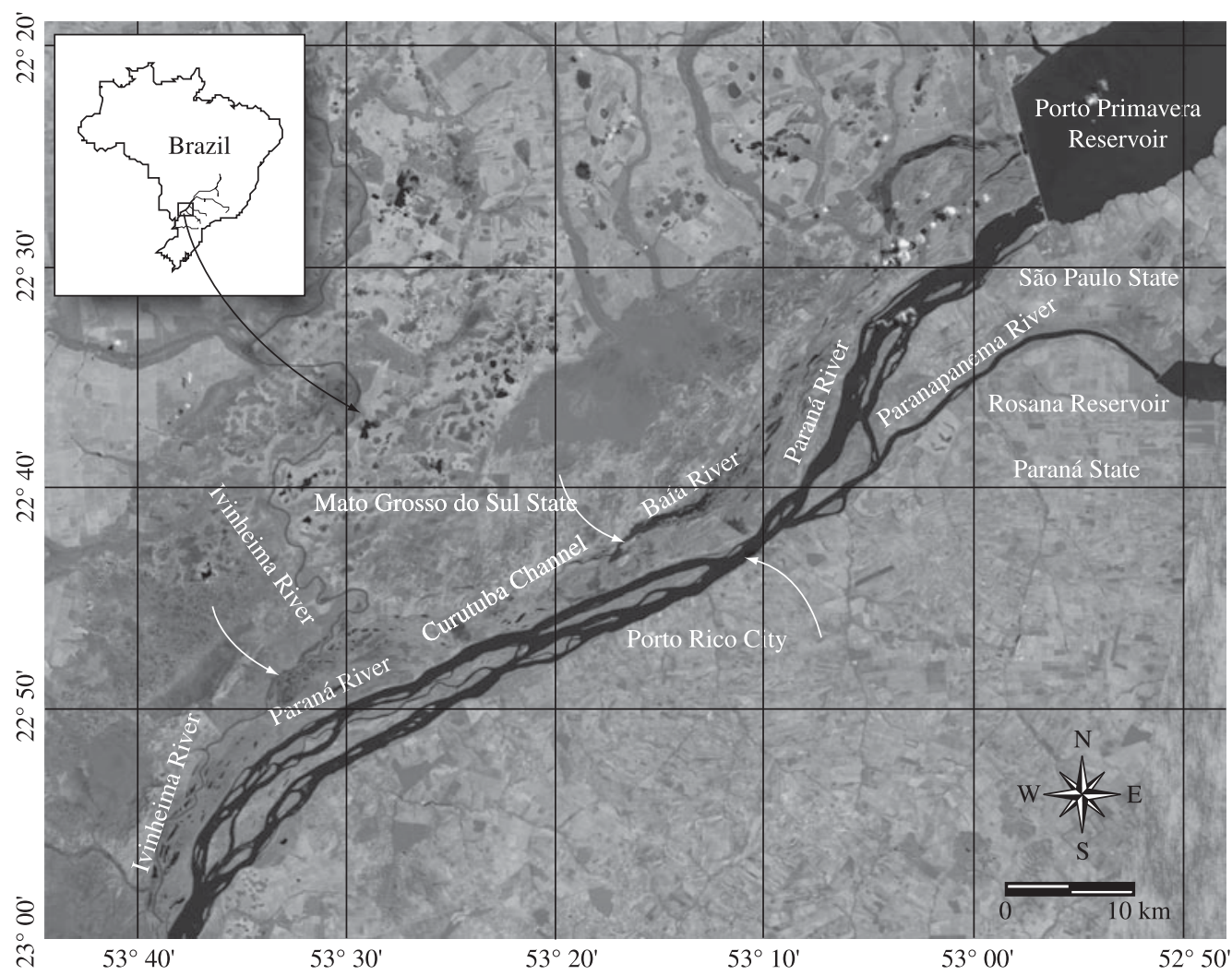

Figure 1. Location and map of the upper Paraná River floodplain (Satellite image LANDSAT 7 - ETM 1999) showing the sampling stations (arrows).

and diminished the watercourse volume (Souza Filho et al., 2004, Souza Filho, 2009).

Samplings were carried out directly at the subsurface (20 $\mathrm{cm}$ depth) in the three rivers. Samplings were performed monthly from March 1993 to February 1994. For this period, we utilized the phytoplankton and abiotic data obtained by Train and Rodrigues $(1998,2004)$ for the Baía River, the Paraná River (Train et al., 2000; Train and Rodrigues, 2004) and the Ivinhema River (Train and Rodrigues, 2004). For 2000, 2002, 2004, 2005, 2006 and 2007 , the samplings were carried out every three months, and every six months during 2001 and 2003.

Phytoplankton density was estimated according to Utermöhl (1958) and the American Public Health Association (1995). Species richness was considered as the number of taxa present in each quantitative sample. Water temperature, $\mathrm{pH}$, electrical conductivity and dissolved oxygen were obtained by portable digital potentiometers. Water transparency was measured with a Secchi disc. Total suspended matter, total phosphorus (TP), soluble reactive phosphorus (SRP), and total nitrogen (TN) (as well as nitrate $\left(\mathrm{N}^{-\mathrm{NO}_{3}}{ }^{-}\right.$) and ammonium $\left(\mathrm{N}^{-\mathrm{NH}_{4}}{ }^{+}\right)$were also determined following the methods described in Roberto et al. (2009). Precipitation, fluviometric levels and discharge of the Paraná and Ivinhema rivers were provided by the Agência Nacional de Águas (ANA) and Itaipu Binacional. Low and high water levels were calculated by the Pulse Program (Neiff and Neiff, 2003). For the Paraná River, periods of low fluviometric levels have been associated with low connectivity of this river to other environments in this floodplain because the entry of water from this river to connected environments begins when water levels surpass $3.5 \mathrm{~m}$ (Thomaz et al., 2004; 2007).

\subsection{Data analysis}

The abiotic variables mentioned above were used in a Principal Components Analysis (PCA) to reduce the number of predictor variables in the multiple regression model (see below). We used mean values for the hydrometric levels of the Paraná and Ivinhema rivers measured over a period of 14 days because there was a temporal lag phase in the effect of fluctuating water levels on phytoplankton (this number was selected by preliminary correlation analysis). For precipitation, values corresponding to the two days prior to sampling were recorded. For the Baía River analysis we used the hydrometric levels of the Paraná River. Detrended Correspondence Analysis (Jongman et al., 1996) was used to determine the major variation in species composition (presence/absence) data and to reveal patterns in community structure. 
Multiple regression analyses were conducted to identify abiotic variables influencing phytoplankton community structure in the three rivers, using the following response variables $(Y i)$ : species richness, total density, density of the main phytoplankton taxonomic groups and the first two DCA axes. The first two principal components were used as covariables ( $P 1$ : axis 1 and $P 2$ : axis 2$)$. The 1993-1994 period (i.e., before the formation of Porto Primavera Reservoir) and the $2000-2007$ period (i.e., after the formation of Porto Primavera Reservoir) were included as model variable - "dummy" $(I)(0=$ before; $1=$ after $)$. A "time" variable $(t)$ was created following the chronologic scale (monthly samplings: 1 to 12 ; bimonthly: $14,16,18$, and so forth). The model was adjusted according to the equation $Y=$ constant $+\left(b_{1} P_{1}\right)+\left(b_{2} P_{2}\right)+$ $\left(b_{3} t\right)+\left(b_{4} I\right)+\left[\left(b_{5}(I t)\right]\right.$. The results were interpreted as follows: $b_{4}$ showed the alteration in the mean level of the variables after formation of the reservoir; $b_{5}$ was used to quantify the effect of Porto Primavera impoundment on the tendencies of the series; the statistics $b_{1}$ and $b_{2}$ measured the influence of environmental factors, synthesized by the first two PCA axes; $b_{3}$ evaluated the existence of some relationship with time before the intervention. Residuals were analyzed to verify the validity of multiple regression assumptions (normal distribution and homogeneity of variances) (Manly, 1994). Another assumption, the temporal autocorrelation (serial correlation), was tested using a Durbin-Watson statistic. Multiple regression analyses were performed using Statistica ${ }^{\text {TM }} 7.1$ software STATISOFT INC., 2005, whereas multivariate analyses (PCA and DCA) were performed using PCORD 4.01 (McCune and Mefford, 1999).

\section{Results}

The highest monthly values of local accumulated precipitation were observed in October 1993 (Figure 2a) and the highest annual means were observed during 2000, 2001, 2003, 2006 and 2007 (Table 1). The annual variability of Paraná River fluviometric levels was high.
Less annual variability occurred during 2000, 2004 and 2006 (Figure 2b, Table 1). A multitude of low-water days occurred during 2000 to 2004 at the Paraná River and throughout the studied period at the Ivinhema River (Table 1).

All three rivers displayed low interannual variation in the monthly mean of water temperature (Table 1). Electric conductivity did not show clear seasonality and lower values occurred in the Baía River. $\mathrm{pH}$ values were around 7.0 for the three rivers. Water transparency was high in the Paraná River in 2004, 2005 and 2006 and low in the Ivinhema and Baía rivers. A clear decrease in suspended material concentrations characterized all three rivers after the formation of Porto Primavera Reservoir, especially in the Paraná River. The lowest nutrient concentrations were registered in the Paraná River; the lowest values were found after 2000 (Table 1). For the Ivinhema River, TN and TP concentrations showed high-

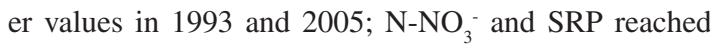
their highest levels in 2000, 2005 and 2006. For the Baía River, $\mathrm{TN}$ and $\mathrm{N}_{-} \mathrm{NO}_{3}^{-}$concentrations presented higher values in 2005 and 2007. TP concentrations were higher in 2003 and SRP was higher in 2003 and 2006.

The first two axes generated by Principal Components Analysis performed with the Paraná River data explained $50 \%$ of total data variability (Figure 3a). Axis 1 was positively correlated with electric conductivity (0.39) and water transparency (0.49), and negatively correlated with water temperature $(-0.31)$, fluviometric level $(-0.43)$, and TP $(-0.45)$. These variables helped to distinguish the months with higher fluviometric levels in the 1993-1994 period. The variables with higher correlations with axis 2 were $\mathrm{pH}(-0.66)$ and total nitrogen $(-0.64)$.

For the Baía River, the first two axes explained $43 \%$ of total data variability (Figure $3 b$ ). Axis 1 was negatively correlated with electric conductivity $(-0.57)$, water temperature (-0.39), fluviometric level $(-0.41)$, and $\mathrm{NO}_{3}$ $(-0.43)$. The variables with higher correlations with axis 2 were water transparency $(-0.55)$, TP $(0.41)$ and SRP (0.55). For the Ivinhema River, the first two axes explained
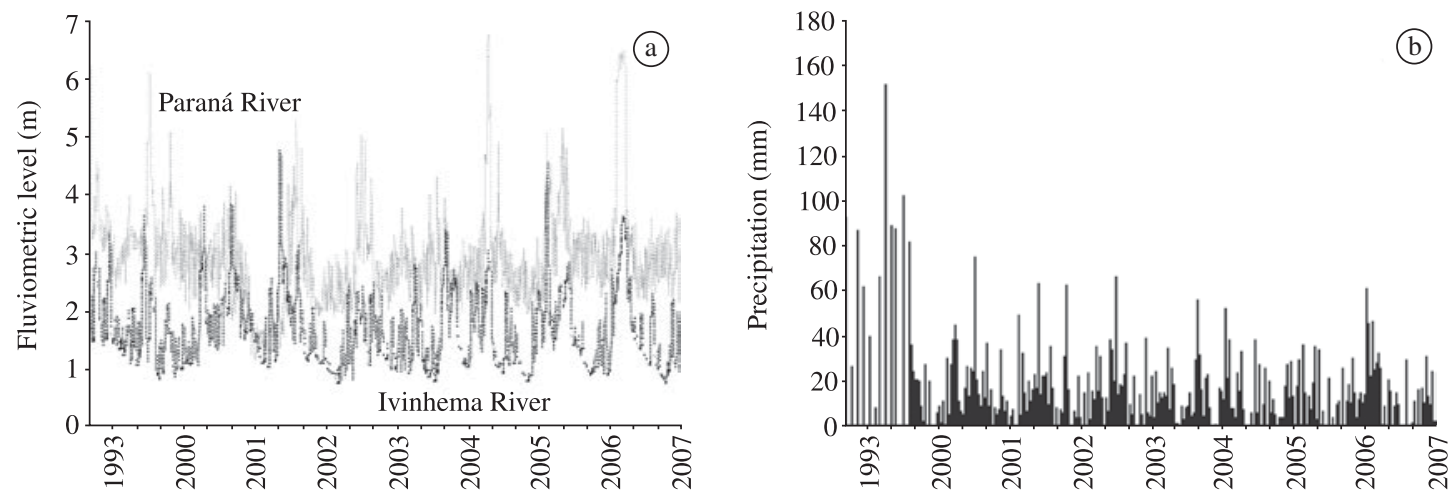

Figure 2. a) Daily fluviometric levels of Paraná and Ivinhema Rivers, and b) precipitation of Paraná River (bars), from March 1993 to February 1994 and 2000 to 2007. Sampling days are indicated by points. Precipitation values during the period from March 1993 to February 1994 refer to the total monthly values 


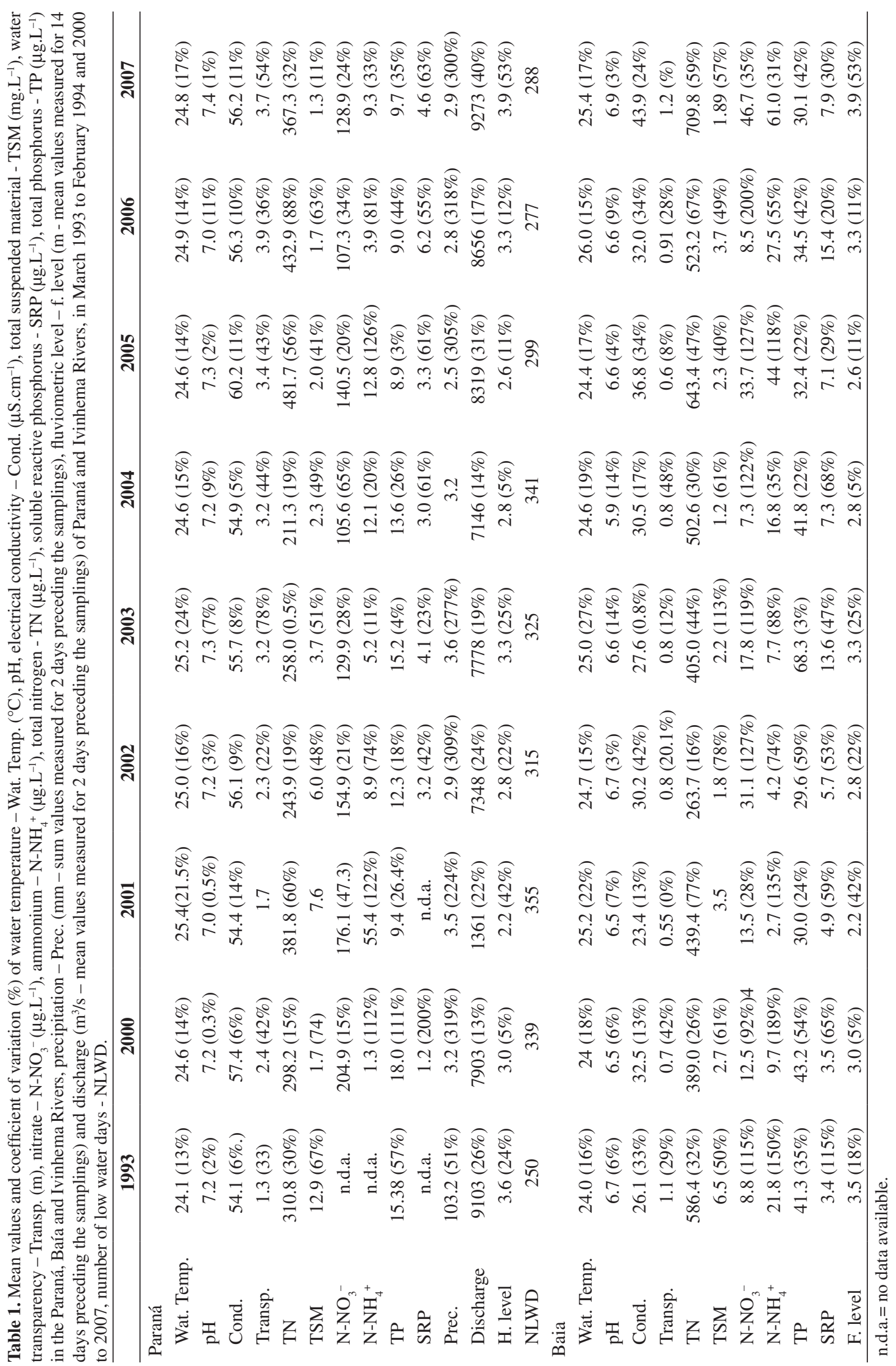




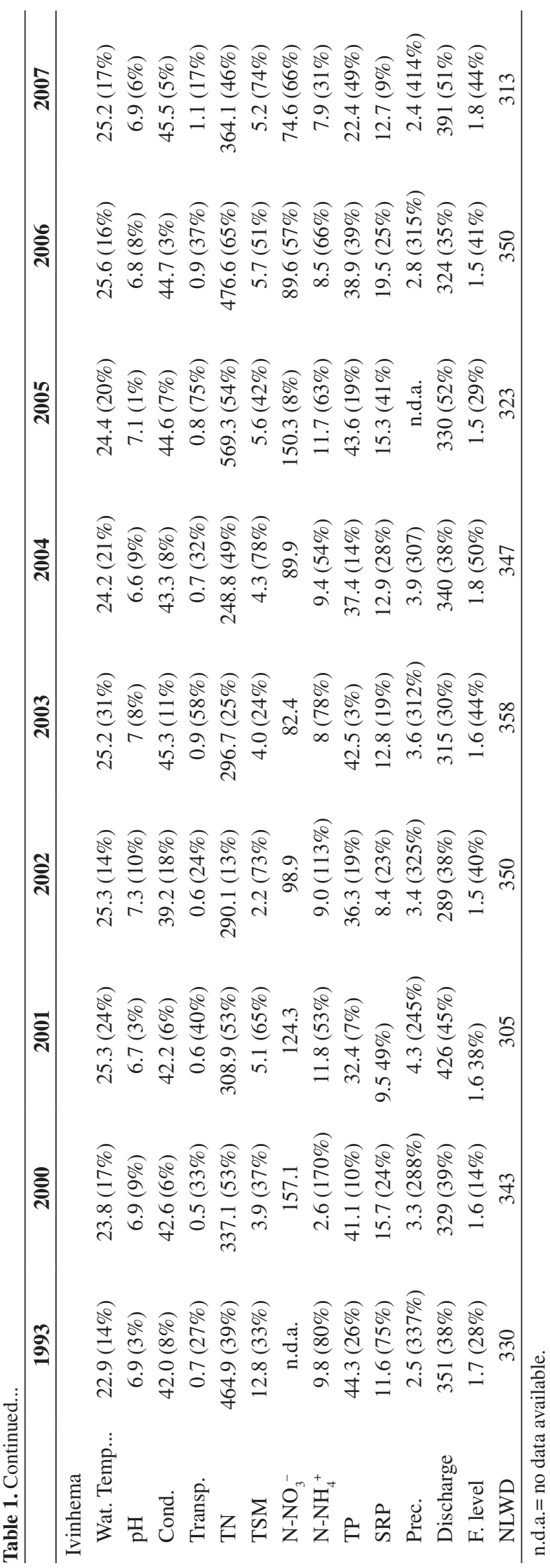



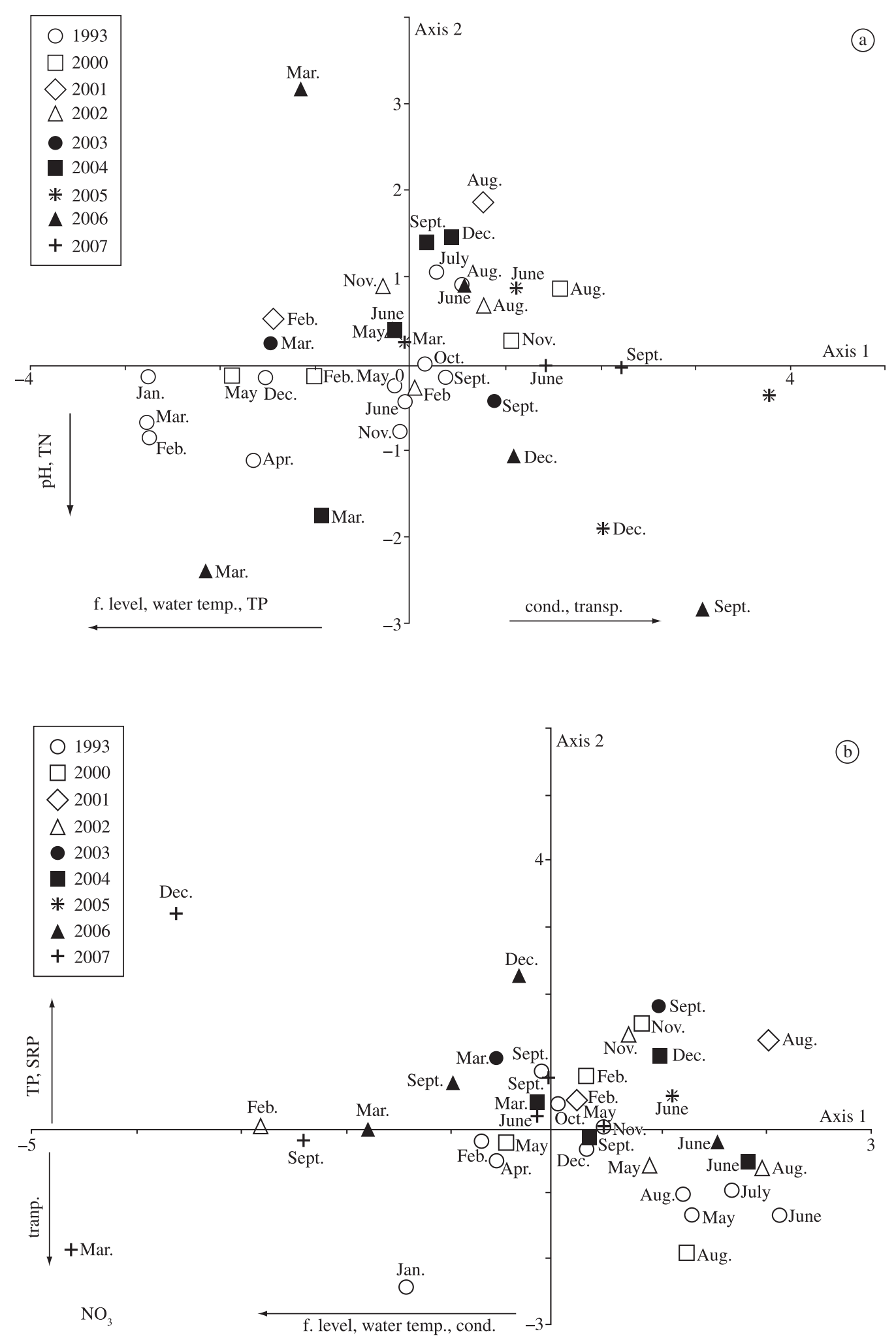

Figure 3. a) Ordination showing the variables most correlated to the axes of a Principal Components Analysis for Paraná River; b) Baía River, and c) Ivinheima River. (See legends in Table 1). 


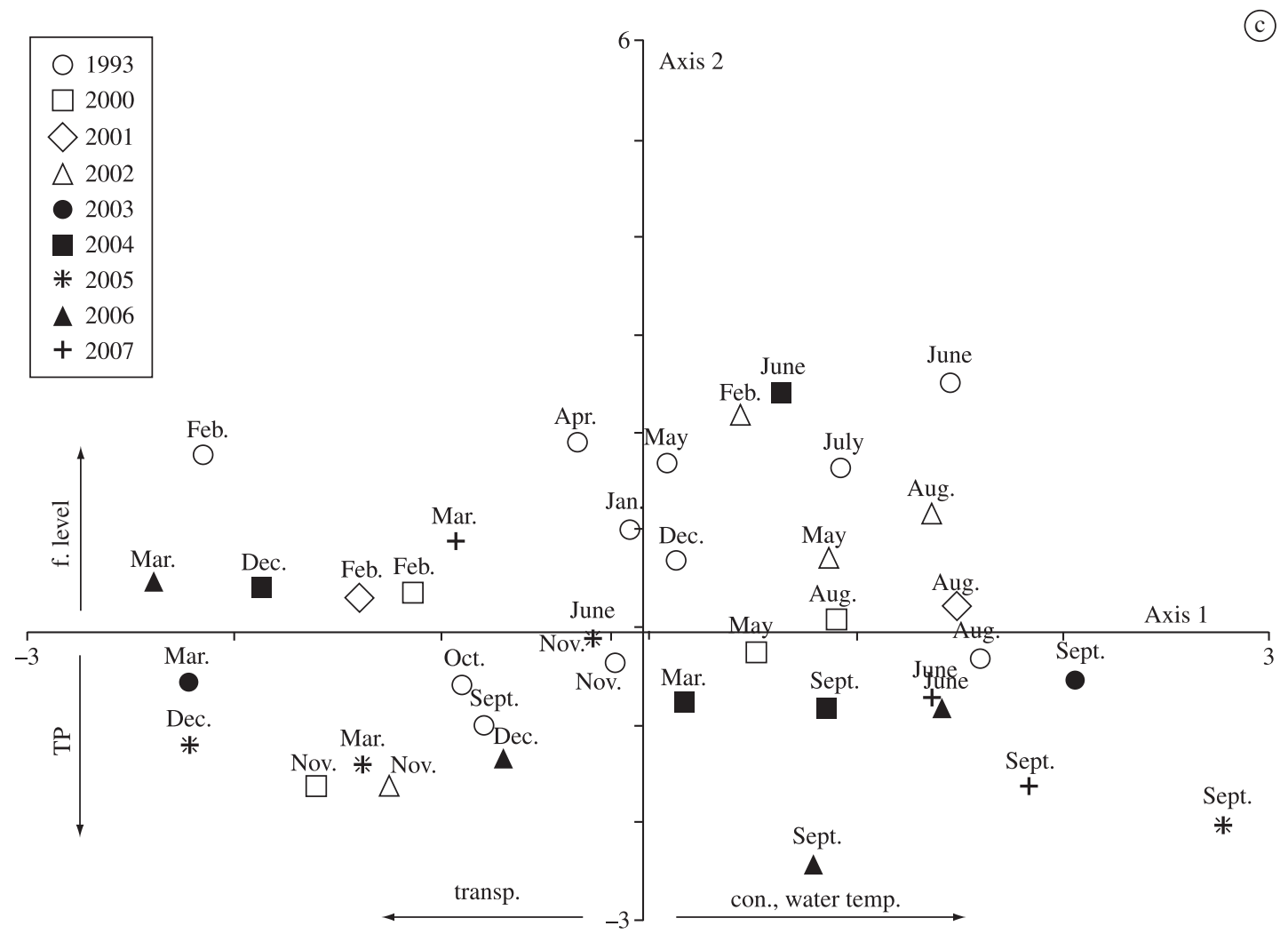

Figure 3 (continued). a) Pearson's correlations among the original abiotic variables and scores in Principal Components Analysis performed for Paraná River; b) Baía River; and c) Ivinhema River. (See legends in Table 1).

$38 \%$ of the total variability (Figure $3 \mathrm{c}$ ). Axis 1 was positively correlated with water transparency $(0.54)$ and negatively with water temperature $(-0.58)$, TN $(-0.18)$ and TP $(-0.35)$. Variables with higher correlations with axis 2 were electrical conductivity $(-0.56), \mathrm{pH}(-0.20)$, nitrate $(-0.37)$, SRP $(-0.37)$ and fluviometric level (0.51).

High number of phytoplankton species were found in the rivers studied (454 taxa): 177 taxa in the Paraná River, 288 in the Baía River and 227 in the Ivinhema River. Diatoms, clorophyceans and cyanobacteria were the most important taxonomic groups in these rivers.

The DCA performed for Paraná and Baía rivers distinguished the period of March 1993 to February 1994 from the other years (Figure 4a, c). After the filling of the Porto Primavera Reservoir, there was a shift in phytoplankton composition, mainly, a decrease in the frequency of diatoms, clorophyceans and zygnemaphyceans and an increase in the occurrence of cyanobacteria. The highest contribution of zygnemaphyceans was observed in Baía River before the impoundment (Figure 4d). The Ivinhema River presented a similar composition throughout all periods (Figure 4e, f).

Species richness did not show a clear pattern between periods, with the highest values registered for the Paraná River in the years following Porto Primavera dam construction (Figure 5). Density values were highest during 2000-2004 in the three rivers studied (Figure 6) and diminished from 2005 to 2007 in the Paraná and Baía Rivers. Diatoms and cyanobacteria contributed significantly to density from March 1993 to February 1994 in these systems (Figure 6a, b, c). In 2000-2007, there was a lower diatom contribution to species richness and a higher cyanobacteria contribution (Figure 5a, b, c). After 2000, cryptomonadas and cyanobacteria dominated with regard to density in different months (Figure 6a, b, c).

Aulacoseira granulata (Ehr.) Sim. and Discostella stelligera (Cleve and Grun.) Holk and Klee were the main diatoms in the three rivers. Chlorophyceae was represented mainly by the Order Chlorococcales and cryptomonadas by Cryptomonas spp. and Chroomonas acuta Uterm. Synechocystis aquatilis Sauv., Radiocystis fernandoi Kom. and Kom.-Legn. and Pseudanabaena mucicola were the most abundant cyanobacteria taxa.

For the Paraná River, multiple regression analysis (Table 2) showed a significant relationship of phytoplankton species richness with the $P l$ and a negative relationship of phytoplankton species richness with $I^{*} t$ variables (61\% explanation). A significant relationship was also registered for DCA 1 and $I^{*} t$ variables $(80 \%$ explanation). A relationship of total density and cyanobacteria density with the $I$ and $P 2$ variables was seen with 

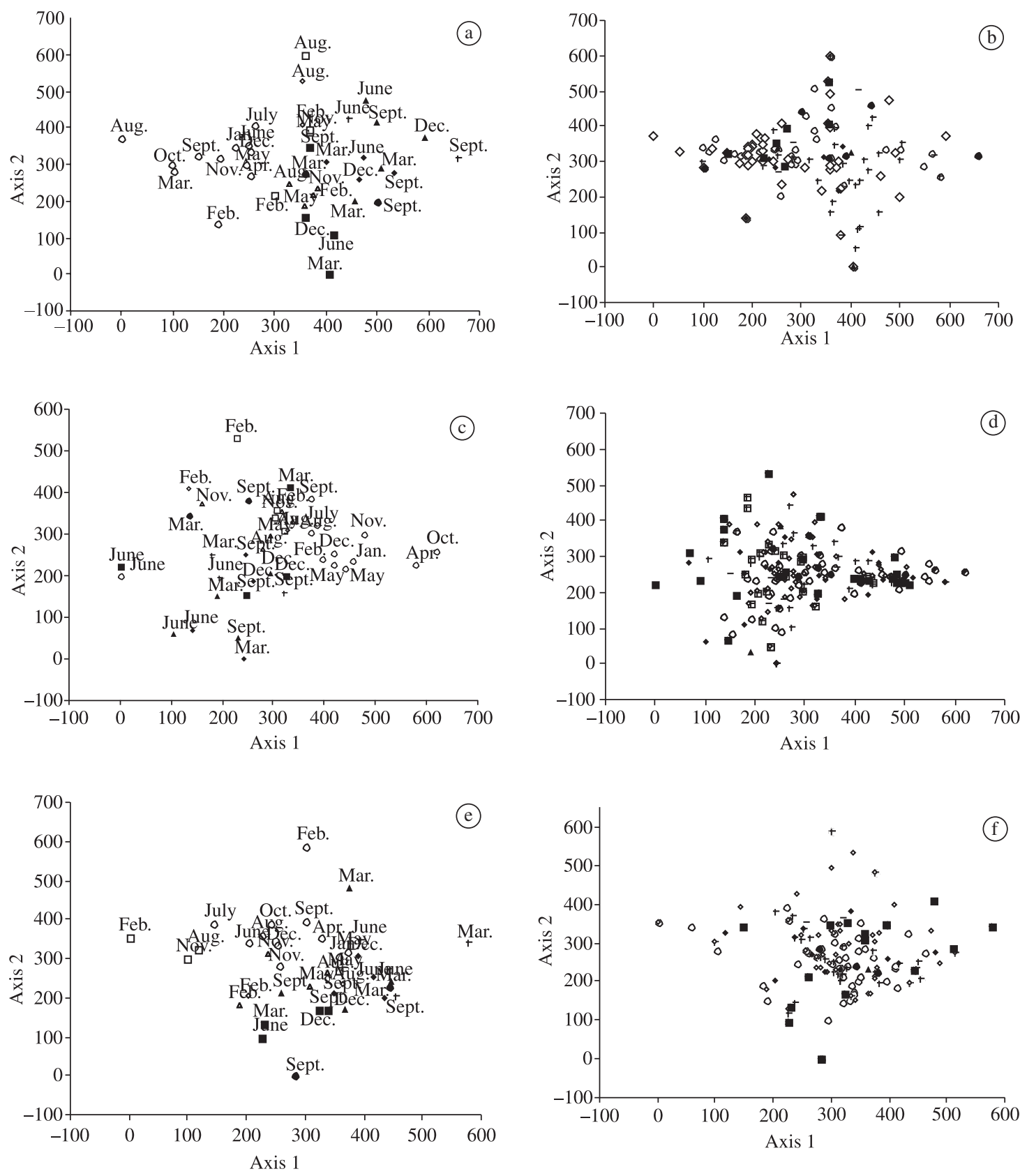

- $1993 \cdot 2001 \cdot 2003 \cdot 2005$

口 $2000 \Delta 2002$ - $2004 \Delta 2006+2007$

- Bacillariophyceae - Chrysophyceae - Zygnemaphyceae + Cyanobacteria - Euglenophyceae ^ Dinophyceae $\diamond$ Chlorophyceae - Cryptophyceae + Xanthophyceae

Figure 4. a) Detrended Correspondence Analysis (DCA) of months and years for species composition (presence/absence) for Paraná River and b) phytoplankton species; c) Detrended Correspondence Analysis (DCA) of months and years for species composition (presence/absence) for Baía River and d) phytoplankton species; e) Detrended Correspondence Analysis (DCA) of months and years species composition (presence/absence) for Ivinhema River and f) phytoplankton species.

$20 \%$ and $46 \%$ explanations, respectively. A relationship was found between diatom density and the $P 1$ variable. The $t$ and $I$ variables were also significant in this model. These variables explained $36 \%$ of the total squared sum of diatom density. A relationship between cryptomonadas density and $t$ and $I$ variables was observed (39\% explanation). A relationship of diatom richness with $t$ and $P 1$ variables was observed (64\% explanation). A rela- 

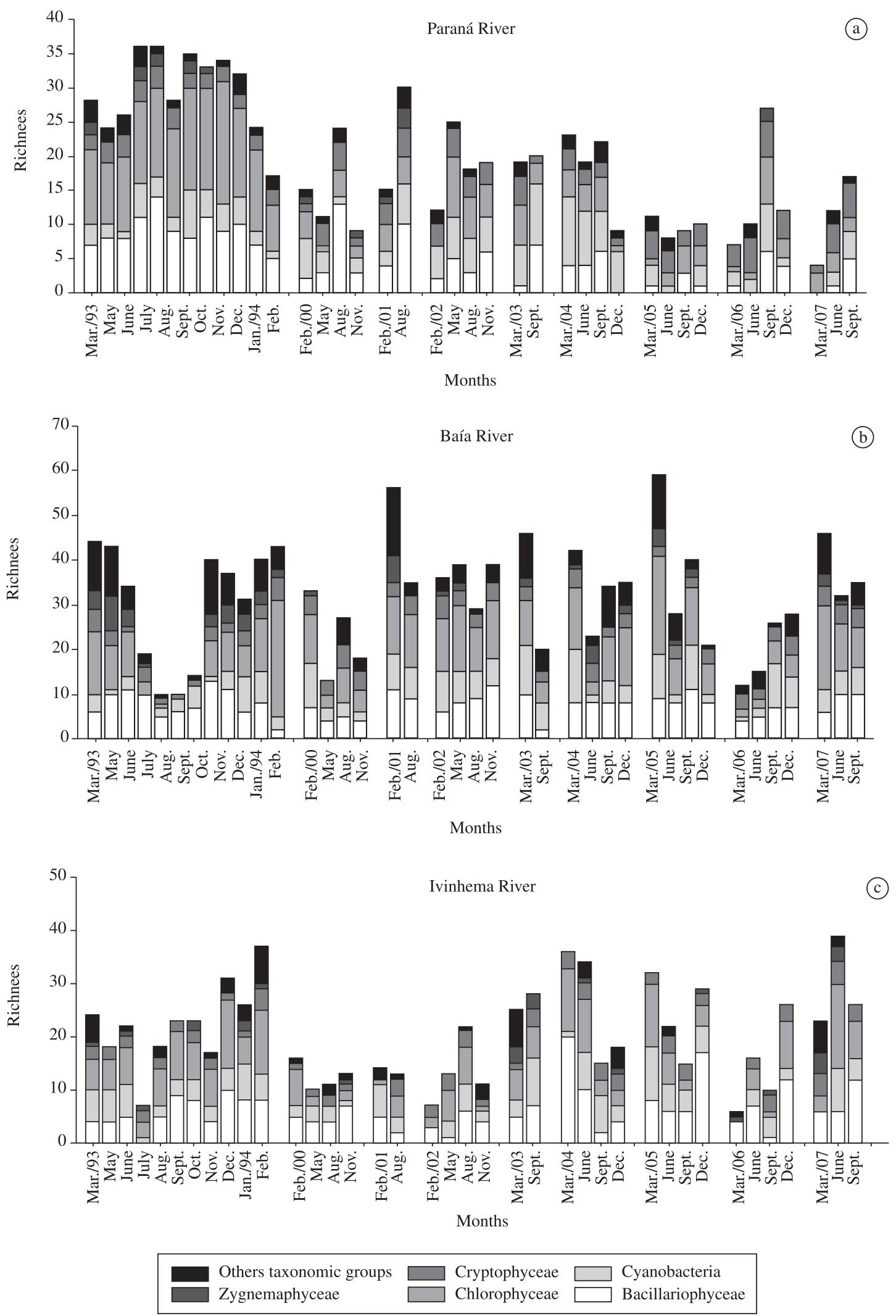

Figure 5. a) Interannual variation of phytoplankton species richness by taxonomic groups in the Paraná River; b) Baía River; and c) Ivinhema River, from March 1993 to February 1994 and 2000 to 2007. 

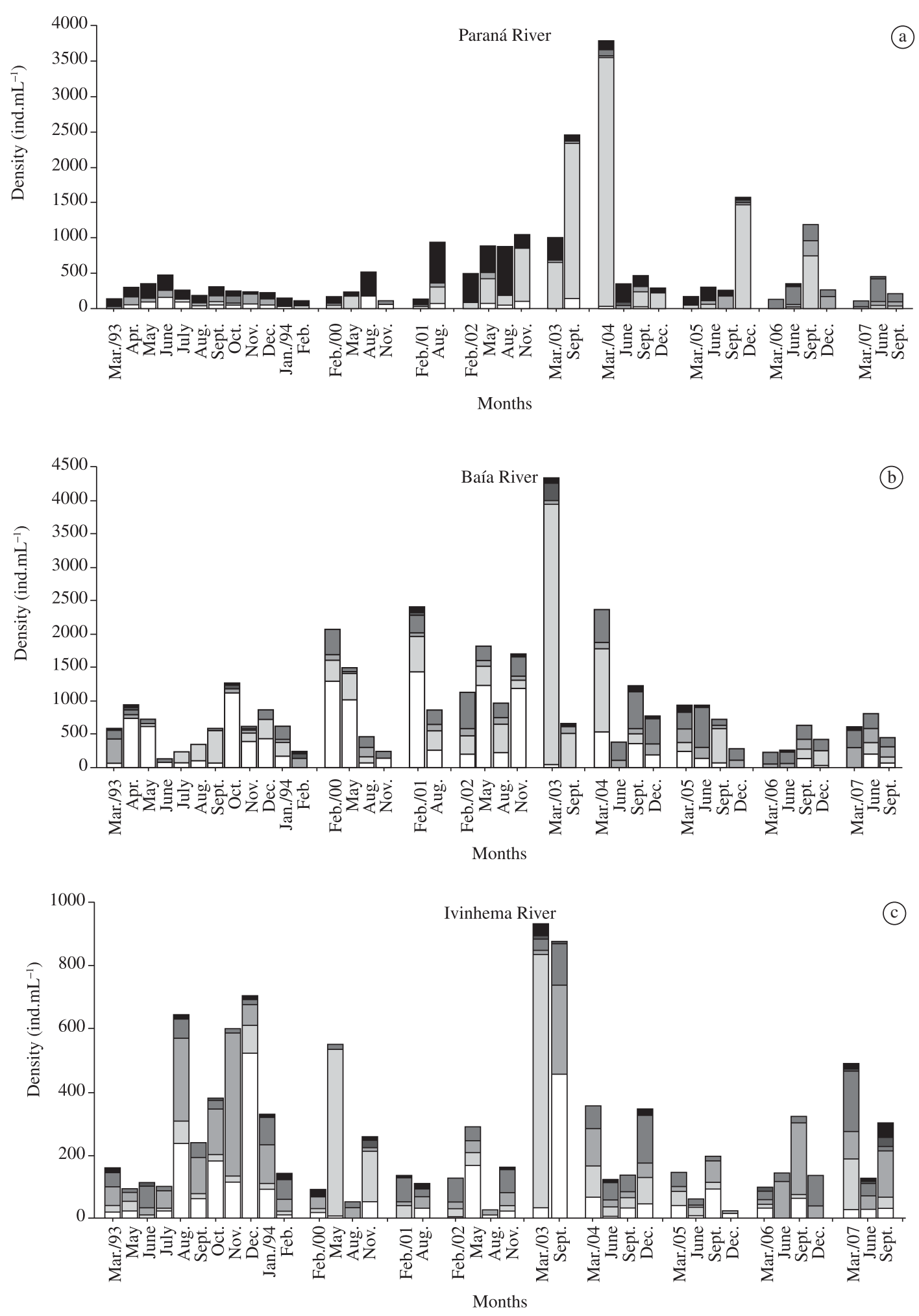

$\begin{array}{ll}\text { Others taxonomic groups } \\ \text { Zygnemaphyceae } & \text { Cryptophyceae } \\ \square \text { Chlorophyceae } & \text { Cyanobacteria } \\ & \square \text { Bacillariophyceae }\end{array}$

Figure 6. a) Interannual variation of phytoplankton density by taxonomic groups in the Paraná River; b) Baía River; and c) Ivinhema River, from March 1993 to February 1994 and 2000 to 2007. 
Table 2. Summary of multiple linear regressions (only significant relationships are shown).

\begin{tabular}{|c|c|c|c|c|c|}
\hline Dependent variables & Explanatory variables & Beta & $\mathbf{t}$ & $\mathbf{p}$ & $\mathbf{R}^{2}$ \\
\hline \multicolumn{6}{|l|}{ Paraná River } \\
\hline DCA 1 & $I^{*} \mathrm{t}$ & 2.25 & 12.24 & $<0.01$ & $80 \%$ \\
\hline \multirow[t]{2}{*}{ Species richness } & $I^{*} \mathrm{t}$ & -0.88 & -7.52 & $<0.01$ & $61 \%$ \\
\hline & Principal component $1(\mathrm{P} 1)$ & 0.31 & 2.70 & $<0.05$ & \\
\hline \multirow[t]{2}{*}{ Total density } & Period (I) & 513.1 & 2.2 & $<0.05$ & $20 \%$ \\
\hline & Principal component $2(\mathrm{P} 2)$ & -209.3 & -2.2 & $<0.05$ & \\
\hline \multirow[t]{2}{*}{ Cyanobacteria density } & Principal component 2 (P2) & -226.7 & -2.5 & $<0.05$ & $46 \%$ \\
\hline & Period (I) & 461.7 & 2.0 & $<0.05$ & \\
\hline \multirow[t]{2}{*}{ Diatom richness } & Time $(\mathrm{t})$ & -0.06 & -7.9 & $<0.01$ & $64 \%$ \\
\hline & Principal component $1(\mathrm{P} 1)$ & 1.03 & 3.63 & $<0.01$ & \\
\hline Clorophycean richness & Period (I) & -7.36 & -3.96 & $<0.01$ & $80 \%$ \\
\hline \multirow[t]{3}{*}{ Diatom density } & Time $(t)$ & -0.96 & -3.68 & $<0.01$ & \\
\hline & Principal component 1 (P1) & 12.5 & 2.81 & $<0.05$ & $36 \%$ \\
\hline & Period (I) & 60.11 & 2.11 & $<0.05$ & \\
\hline \multirow[t]{2}{*}{ Cryptomonada density } & Time $(\mathrm{t})$ & 1.68 & 4.3 & $<0.01$ & $39 \%$ \\
\hline & Period (I) & -128.8 & -2.88 & $<0.05$ & \\
\hline \multicolumn{6}{|l|}{ Ivinhema River } \\
\hline \multirow[t]{2}{*}{ DCA 2} & Principal component $1(\mathrm{P} 1)$ & -29.2 & 2.8 & $<0.05$ & $72 \%$ \\
\hline & $I^{*} \mathrm{t}$ & -3.2 & -3.7 & $<0.01$ & \\
\hline Species richness & Period (I) & -31.4 & -2.9 & $<0.05$ & $46 \%$ \\
\hline \multirow[t]{2}{*}{ Cryptomonada richness } & Time $(\mathrm{t})$ & 0.03 & 3.41 & $<0.05$ & $44 \%$ \\
\hline & Period (I) & -2.6 & -2.9 & $<0.01$ & \\
\hline Diatom density & Principal component $1(\mathrm{P} 1)$ & 47.7 & 2.42 & $<0.05$ & $37 \%$ \\
\hline \multirow[t]{2}{*}{ Clorophycean density } & Principal component $1(\mathrm{P} 1)$ & 29.8 & 2.1 & $<0.05$ & $48 \%$ \\
\hline & Principal component $2(\mathrm{P} 2)$ & -41.5 & -2.8 & $<0.05$ & \\
\hline \multirow[t]{2}{*}{ Cryptomonada density } & Time $(t)$ & 1.4 & 3.3 & $<0.01$ & $34 \%$ \\
\hline & Period (I) & -97.6 & -2.7 & $<0.05$ & \\
\hline \multicolumn{6}{|l|}{ Baía River } \\
\hline DCA 1 & Period (I) & -0.63 & -4.45 & $<0.01$ & $41 \%$ \\
\hline Cyanobacteria richness & Time $(\mathrm{t})$ & 3.15 & 2.1 & $<0.05$ & $21 \%$ \\
\hline
\end{tabular}

tionship between clorophyceans richness and the $I$ variable was also observed (80\% explanation).

For the Ivinhema River, the multiple regression analysis (Table 2) showed a significant relationship between phytoplankton species richness and the $I$ variable (46\%). A significant relationship was also registered for DCA 2 with the $P 1$ and $I * t$ variables ( $72 \%$ explanation). A relationship of cryptomonadas density and richness with $t$ and $I$ variables was observed. These variables explained $34 \%$ and $44 \%$ of the total squared sum of cryptomonadas density and richness, respectively. A relationship was found between diatom density and the $P 1$ variable (37\% explanation). A relationship between clorophyceans density and the $P 1$ and $P 2$ variables was also observed; together these explained $48 \%$ of the total squared sum.

For the Baía River, multiple regression analysis (Table 2) showed a significant relationship of DCA 1 with the $I$ variable ( $41 \%$ explanation). A relationship between cyanobacteria richness with the $t$ variable was observed ( $21 \%$ of explanation).

\section{Discussion}

Species richness in the three studied rivers was higher than that registered in high turbidity rivers (Borges et al., 2003; Soares et al., 2007). However, the values were lower than those recorded for downstream reservoir lotic systems of the Paranapanema basin (Ferrareze and Nogueira, 2006) and for other stretches of the upper Paraná River (Zalocar de Domitrovic et al., 2007) (except for the Baía River, which demonstrated similar values).

Lowest phytoplankton density was observed during the potamophase (defined as material and energy flows that occur as pulses in a high water periods, sensu Neiff, 1996) in 1993-1994, when fluviometric levels and suspended material concentrations were highest (Train and 
Rodrigues, 2004). Similar results were also recorded during the 2002-2007 period.

The potamoplankton of the Ivinhema River, similar to other rivers of the world that are not yet regulated (Reynolds and Descy, 1996; Soares et al., 2007), was characterized by low density and a high proportion of rare species. The Baía and Paraná rivers showed greater density than other stretches of the upper Paraná River, studied by Zalocar de Domitrovic et al. (2007), principally during 2003 and 2004, after the filling of the Porto Primavera Reservoir.

Due to the discharge regulation of the upper Paraná River by reservoirs located upstream (Souza Filho, 2009), mainly Porto Primavera, pronounced floods of this river will only happen when the reservoir reaches maximum capacity, during periods of intense precipitation (Souza Filho et al., 2004) (such as occurred during January 2005 and 2007). Both periods were under the influence of El Niño events (not sampled in this study). This phenomenon has been strongly and positively correlated with increased Paraná River discharge (Amarasekera et al., 1997; Camilloni and Barros, 2003).

The absence of pronounced floods in the upper Paraná River floodplain during 2000 and 2001 (Train et al., 2004; Borges and Train, 2009) has been attributed specially to low precipitation, and discharge regulation, resulting from the operational procedures of upstream dams. These procedures cause remarkable variation in the fluviometric levels of Paraná River, and such effects were intensified after the formation of Porto Primavera Reservoir.

Those years were characterized by low precipitation and fluviometric levels at the Paraná River, due to the influence of La Niña (McPhaden et al., 2006), and there was a drastic reduction in the level of water from upstream reservoirs. This resulted in reduced connectivity among the Paraná, Baía and Ivinhema rivers and their associated environments, which probably influenced the low values of species richness and high density values, especially in the Baia River. These results emphasize the importance of connectivity with regard to innocula and nutrient sources for the main river channel, as suggested in other studies (Zalocar de Domitrovic et al., 2007; Ferrareze and Nogueira, 2006).

The influence of Paraná River hydrometric levels and discharge on phytoplankton was evaluated in this study by the direct relationship of species richness to principal component 1 , obtained by the multiple regression analysis performed for the Paraná River. The significant relationship of DCA axis 1 with the $I^{*} t$ variable (used to quantify the effect of Porto Primavera impoundment on the tendencies of the series) suggests changes in the phytoplankton composition of the Paraná River due to the influence of this reservoir. Temporal trajectories of species richness values differed between the phases (before and after impoundment).

The decline of Bacillariophyceae richness and density in the Paraná and Ivinhema rivers confirms their tolerance for lower transparency and turbulence conditions, such as those registered in the period before the construction of the Porto Primavera Reservoir. Centric diatoms are, in general, adapted to lotic conditions due to the capacity for rapid growth, a high surface:volume ratio, and a low threshold for light saturation (Reynolds, 1994; Reynolds and Descy, 1996).

Cyanobacteria species are sensitive to conditions of high discharge, forming blooms in reservoirs that present high retention time and nutrient availability (Harris and Baxter, 1996; Rodrigues et al., 2005; Silva et al., 2005; Train et al., 2005). Such an alteration in a series' mean level of cyanobacteria density, observed in the Paraná River after formation of the reservoir (positive relationship of cyanobacteria density to variable $I$ - "dummy" (I) $(0=$ before; $1=$ after $))$, is probably due to upstream reservoir innocula transport.

In this sense, we can assert that there is a direct influence of upstream reservoirs on phytoplankton from the upper Paraná River, considering the proximity between the sampled stretch of Paraná River and the upstream region immediately downstream from Porto Primavera and Rosana reservoirs (the latter located at the Paranapanema River). Thus, the high densities registered in 2003 and 2004 indicate the presence of algae input from upstream reservoirs. This statement is further supported by the similarity in the phytoplankton composition of communities from the Rosana Reservoir and the Paraná River (Train et al., 2005; Borges et al., 2008b).

The significant differences between periods with regard to species richness were also verified for the Baía River, as demonstrated by the relationship between cyanobacteria richness and variable $I$. In addition, our report that the same species of cyanobacteria are dominants in the Paraná and Baía rivers further supports our assertion of the influence of the Paraná River on the Baía River.

The remarkable decrease in volume of the Baía River after construction of the Porto Primavera dam (Souza-Filho et al., 2004) promoted an increase of the cyanobacteria population, principally in March 2003, as verified in rivers with low discharge where water retention time is greater and also at the same river in an earlier study (Train and Rodrigues, 1998).

The lower contribution of zygnemaphyceans to phytoplankton community composition in the Baía River after the impoundment may be related to decreased water transparency (Happey-Wood, 1988). Reduced water transparency in the Baía River after the Porto Primavera impoundment can be attributed to discharge regulation of the upper Paraná River by this reservoir, as well as the reduced frequency of high-water periods. According to Thomaz et al. (2004), with regard to water transparency, $72 \%$ of the values lower than $1 \mathrm{~m}$ were recorded in the Baía River, in low-water periods during the years 1986-1995 and 2000.

The lower proportion of Aulacoseira granulata in the Baía and Paraná rivers after the formation of Porto 
Primavera Reservoir, when the discharge of these rivers decreased, shows dependence of this taxa upon turbulence for suspension (Reynolds et al., 2002). In addition, beside the loss due to sedimentation, Aulacoseira require innocula from adjacent water bodies for growth in the main river (Garcia de Emiliani, 1990). In this sense, the hydrodynamic characteristics of the lacustrine region of reservoirs does not seem to allow the development of this population, reducing the source of innocula encountered downstream in the studied stretch of the upper Paraná River.

The phytoplankton composition changes in the Paraná and Baía rivers were not recorded for the Ivinhema River, except in March 2003, when we observed high Synechocystis aquatilis (cyanobacteria) density. This fact indicates that the Ivinhema River still displays relatively pristine conditions which are less affected by the Paraná River, except in cases of exceptional floods, when the fluviometric level of the Paraná River is higher than 4.5 meters (Souza-Filho et al., 2004).

Operational procedures of upstream dams have influenced interannual and seasonal variability of phytoplankton communities in the Paraná River. However, the sampling delay between 1994 and 2000 and climatic changes caused by El Niño and La Niña, do not allow us to assign a single factor responsible for the differences observed in the phytoplankton community structure. In 2000 and 2001 , there was certainly a synergism between the reservoir effects and the occurrence of extreme drought. Thus, climatic alterations, in addition to changes resulting from the construction of Porto Primavera Reservoir, should be considered as explanatory factors in analysis of the interannual variability of phytoplankton communities in these rivers.

Acknowledgements - The authors are grateful to the Núcleo de Pesquisas em Limnologia, Ictiologia e Aqüicultura (Nupélia) at Universidade Estadual de Maringá for logistic support; to researchers of the Limnology Laboratory of Nupélia for determining water abiotic factors, to Dr. Luis Maurício Bini for help in numerical analysis and to CNPq/PELD (site 6) for financial support.

\section{References}

AGOSTINHO, AA., PELICICE, FM. and GOMES, LC., 2008. Dams and the fish fauna of the Neotropical region: impacts and management related to diversity and fisheries. Revista Brasileira de Biologia = Brazilian Journal of Biology, vol. 68, no. 4, p. 1119-1132.

AMARASEKERA, KN., LEE, RF., WILLIANS, ER. and ELTAHIR, EAB., 1997. ENSO and variability in the flow of tropical Rivers. Journal of Hidrology, vol. 200, no. 1-4, p. 24-39.

AMERICAN PUBLIC HEALTH ASSOCIATION - APHA, 1995. Standard methods for the examination of water and wasterwater. Washington: Byrd Prepress Springfield. $1134 \mathrm{p}$.
BORGES, PAF. and TRAIN, S., 2009. Phytoplankton diversity in the Upper Paraná River floodplain during two years of drought (2000 and 2001). Revista Brasileira de Biologia = Brazilian Journal of Biology, vol. 69, no. (2 suppl), p. 637-647.

BORGES, PAF., RODRIGUES, LC., PAGIORO, TA. and TRAIN, S., 2003. Spatial variation of phytoplankton and some abiotic variables in the Pirapó River - PR (Brazil) in August 1999: a preliminary study. Acta Scientiarum Biological Sciences, vol. 25, no. 1, p. 1-8.

BORGES, PAF., TRAIN, S. and RODRIGUES, LC., 2008a. Estrutura do fitoplâncton, em curto período de tempo, em um braço do reservatório de Rosana (ribeirão do Corvo, Paraná, Brasil). Acta Scientiarum Biological Sciences, vol. 30, no. 1, p. $57-65$.

2008b. Spatial and temporal variation of phytoplankton in two subtropical Brazilian reservoirs. Hydrobiologia, vol. 607, no. 1, p. 63-74.

BOVO-SCOMPARIN, VM. and TRAIN, S., 2008. Longterm variability of the phytoplankton community in an isolated floodplain lake of the Ivinhema River State Park, Brazil. Hydrobiologia, vol. 610, no. 1, p. 331-344.

CAMILLONI, IA. and BARROS, VR., 2003. Extreme dischargue events in the Paraná River and their climate forcing. Journal of Hydrology, vol. 278, no. 1-4, p. 94-106.

DEVERCELLI, M., 2006. Phytoplankton of the Middle Paraná River during an anomalous hydrological period: a morphological and functional approach. Hydrobiologia, vol. 563 , no. 1, p. $465-478$.

FERRAREZE, M. and NOGUEIRA, MG., 2006. Phytoplankton assemblages and limnological characteristics in lotic systems of the Paranapanema Basin (Southeast Brazil). Acta limnologica Braziliensia, vol. 18, no. 4, p. 389-405.

GARCIA De EMILIANI, MO., 1990. Phytoplankton Ecology of the middle Paraná River. Acta Limnologica Brasiliensia, vol. 3, no. 1, p. 391-417.

HAPPEY-WOOD, C., 1988. Ecology of freshwater planktonic green-algae. In SANDGREEN, CD. (Ed.). Growth and reproductive strategies of freshwater phytoplankton. Cambridge: Cambridge University Press. p. 175-226.

HARRIS, GP. and BAXTER, G., 1996. Interannual variability in the phytoplankton biomass and species composition in a subtropical reservoir. Freshwater biology, vol. 35, no. 3, p. $545-560$.

JONGMAN, RHG., TER BRAAK, CJF. and VAN TONGEREN, OFR., 1996. Data analysis in community and landscape ecology. Cambridge: University Press. 299p.

LAIR, N. and REYES-MARCHANT, P., 1997. The potamoplankton of the Middle Loire and the role of the 'moving litoral' in downstream transfer of algae and rotifers. Hydrobiologia, vol. 356, no. 1-3, p. 33-52. 
MANLY, BFG., 1994. A Primer of multivariate statistics. London: Chapmam \& Hall. 179p.

McCUNE, B. and MEFFORD, MJ., 1999. PC-ORD: multivariate analysis of ecological data, version 4.0. MjM Software Design. Oregon: Gleneden Blach.

McPHADEN, MJ., ZEBIAK, SE. and GLANTZ, MH., 2006. ENSO as an integrating concept in Earth Science. Science, vol. 314 , no. 5806, p. 1740-1745.

NEIFF, JJ. and NEIFF, M., 2003. PULSO 1.1, software para análisis de fenómenos recurrentes. Dirección Nacional de Derecho de Autor No. 236164 (Argentina) Buenos Aires. Available from: <http://www.neiff.com.ar>. Access in: $15 \mathrm{de}$ junho de 2008.

NEIFF, JJ., 1996. Large Rivers of South America: toward the new approach. Verhandlungen Internationale Vereinigung Limnologie, vol. 26, no. 1, p. 167-181.

REYNOLDS, CS., 1994. The long, the short and the stalled: on the attributes of phytoplankton selected by physical mixing in lakes and Rivers. Hydrobiologia, vol. 289, no. 1-3, p. 9-21.

REYNOLDS, CS. and DESCY, JP., 1996. The production, biomass and structure of phytoplankton in large Rivers. Archiv für Hydrobiologie/Supplement band, vol. 113, no. 1-4, p. 161-187.

REYNOLDS, CS., HUSZAR, VLM., KRUK, C., NASELLIFLORES, L. and MELO, S., 2002. Towards a functional classification of the freshwater phytoplankton. Journal of Plankton Research, vol. 24, no. 5, p. 417-428.

ROBERTO, MC., SANTANA, NF. and THOMAZ, SM., 2009. Limnology in the Upper Paraná River floodplain: large-scale spatial and temporal patterns, and the influence of reservoirs. Revista Brasileira de Biologia $=$ Brazilian Journal of Biology, vol. 69, no. (2 suppl), p. 717-725.

RODRIGUES, LC., TRAIN, S., PIVATO, BM, BOVOSCOMPARIN, VM., BORGES, PAF. and JATI, S., 2005. Assembléias fitoplanctônicas de 30 Reservatórios do estado do Paraná. In RODRIGUES, L., THOMAZ, SM., AGOSTINHO, AA. and GOMES, LC. Biocenoses em reservatórios: padrões espaciais e temporais. São Carlos: RIMA. p. 57-72.

ROJO, C., COLBELAS, MA. and ARAUZO, M., 1994. An elementary structure analysis of the river phytoplankton. Hydrobiologia, vol. 285, no. 1-3, p. 43-55.

SILVA, CA., TRAIN, S. and RODRIGUES, LC., 2001. Estrutura e dinâmica da comunidade fitoplanctônica a jusante e montante do reservatório de Corumbá, Caldas Novas, Estado de Goiás, Brasil. Acta Scientiarum, vol. 23, no. 1-3, p. 283-290.

2005. Phytoplankton assemblages in a Brazilian subtropical cascading reservoir system. Hydrobiologia, vol. 537, no. 1-3, p. 99-109.
SOARES, MCS., HUSZAR, VLM. and ROLAND, F., 2007. Phytoplankton dynamics in two tropical Rivers with different degrees of human impact (Southeast Brazil). River Research and Applications, vol. 23, no. 7, p. 698-714.

SOUZA FILHO, EE., 2009. Evaluation of the Upper Paraná River discharge controlled by reservoirs. Revista Brasileira de Biologia = Brazilian Journal of Biology, vol. 69, no. (2 suppl), p. 707-716.

SOUZA FILHO, EE., ROCHA, PC., COMUNELlO, E. and STEVAUX, JC., 2004. Effects of the Porto Primavera Dam on physical environment of the dowstream floodplain. In THOMAZ, SM., AGOSTINHO, AA. and HAHN, NS. (Eds.). The Upper Paraná river and its floodplain: physical aspects, ecology and conservation. Leiden: Backhuys Publishers. p. 55-74.

STATISOFT INC., 2005. Statistica (data analysis software system) version 7.1. Available from: <www.statisoft.inc $>$.

THOMAZ, SM., BINI, LM. and BOZELLI, RL., 2007. Floods increase similarity among aquatic habitats in riverfloodplain systems. Hydrobiologia, vol. 579, no. 1, p. 1-13.

THOMAZ, SM., PAGIORO, TA., BINI, LM., ROBERTO, MC. and ROCHA, RRA., 2004. Limnological characterization of the aquatic environments and the influence of hydrometric levels. In THOMAZ, SM., AGOSTINHO, AA. and HAHN, NS. (Eds.). The upper Paraná River and its floodplain: physical aspects, ecology and conservation. Leiden: Backhuys Publishers. p. 75-102.

TRAIN, S. and RODRIGUES, LC., 1998. Temporal fluctuations of the phytoplankton community of the Baía River, in the upper Paraná River floodplain, Mato Grosso do Sul, Brazil. Hydrobiologia, vol. 361, no. 1-3, p. 125-134.

TRAIN, S. and RODRIGUES, LC., 2004. Phytoplankton assemblages. In THOMAZ, SM., AGOSTINHO, AA., HAHN, NS. (Eds.). The Upper Paraná river floodplain: physical aspects, ecology and conservation. Netherlands: Backhuys. p. 103-124.

TRAIN, S., JATI, S., RODRIGUES, LC. and PIVATO, BM., 2005. Distribuição espacial e temporal do fitoplâncton em três reservatórios da Bacia do Rio Paraná. In RODRIGUES, L., THOMAZ, SM., AGOSTINHO, AA. and GOMES, LC. (Eds.). Biocenoses em reservatórios: padrões espaciais e temporais. São Carlos: RIMA. p. 73-85.

TRAIN, S., OLIVEIRA, MD. and QUEVEDO, MT., 2000. Dinâmica sazonal da comunidade fitoplanctônica de um Canal Lateral (Canal Cortado) do Alto Rio Paraná (PR, Brasil). Acta Scientiarum, vol. 22, no. 2, p. 389-395.

TRAIN, S., RODRIGUES, LC., BOVO, VM., BORGES, PAF. and PIVATO, BM., 2004. Phytoplankton composition and biomass in environments of the Upper Paraná river. In AGOSTINHO, AA., RODRIGUES, L., GOMES, LC., THOMAZ, SM. and MIRANDA, LE. (Eds.). Structure and functioning of the Paraná river and its floodplain. Maringá: EDUEM. p. 63-74.

UTERMÖHL, H., 1958. Zur Vervollkommnung der quantitativen phytoplankton-methodic. Mitteilungen 
Internationale Vereinigung für Theoretische und Angewandte Limnologie, vol. 9, p. 1-38.

WARD, JV., TOCKNER, K. and SCHIEMER, F., 1999. Biodiversity of floodplains river ecosystems: ecotones and connectivity. Regulated Rivers: Research and Management, vol. 15, no. 1-3, p. 125-139.
ZALOCAR De DOMITROVIC, Y., POI De NEIFF, ASG. and CASCO, SL., 2007. Abundance and diversity of phytoplankton in the Paraná River (Argentina) $220 \mathrm{~km}$ downstream of the Yacyretá reservoir. Revista Brasileira de Biologia = Brazilian Journal Biology, vol. 67, no. 1, p. $53-63$. 